\title{
El invierno que se fue
}

\section{Ana Michelle Díaz-Gutiérrez}

En los días de mayo,

nosotros no lloramos,

llovemos,

sin que nos mires,

lloviznamos.

En invierno,

cuando es verano,

cuando es otoño,

en primavera.

Si pudiera te haría poema,

pero sólo eres unos renglones:

las cuatro letras de tu nombre,

tu sonrisa de estrellas,

el lunar de tu espalda.

Y mis manos que encierran mi cariño

se abren:

para aceptar que sigues en un lago,

cercado,

húmedo,

alienado.

Mi cielo azul se parte. 
No soportaré tus amores no frustrados,

fructíferos y sanos,

no como éste:

un racimo de flores violetas,

de aroma afrutado.

¿Qué tuvimos?

Un puñado de horas dulces,

algunas palabras,

sólo algunas,

el amor nos comió la lengua.

Los besos, abrazos y suspiros,

no te los devuelvo,

me quedo tus sonrisas,

la frialdad

y el desencanto.

Mi amor orgánico,

de hojas verdes y aroma a tierra mojada,

que quede en una postal,

que pase el tiempo y se desvanezca.

Me perdono todo,

los errores de los días pasados,

el cariño.

Y si hubiera algo que perdonarte...

te perdono.

Aunque eso no signifique

que permita que tomes mis flores

sólo para tirarlas.

La lluvia de mis ojos,

es una ofrenda para el tiempo.

Quiero con el sol de la tarde,

bañarme la mirada.

Quiero, con la lluvia,

depurar los cristales de tu miedo. 
Tu miedo inorgánico,

de silicio y cristales de sal,

no lo quiero.

Lo enterraré en tus jardines de arena.

Si fuera semilla,

que algo crezca.

Y deseo que nada surja y clame al cielo.

Descuida, la naturaleza es sabia,

quizá sean estrellas.

El amor,

de tronco fuerte

magnolias regias,

lustrosas hojas,

no depende de mí, crece, vive.

Aún hay luz para ver mientras te escribo;

pero brilla el jardín por nuestra ausencia.

Ana Michelle Díaz Gutiérrez. Química Farmacéutica Bióloga por la Universidad Autónoma del Estado de México (UAEM), México. Actualmente se desempeña como química en el área de validación de procesos de manufactura y holding time en la industria farmacéutica en el Estado de México. Entre sus intereses se encuentra la innovación operacional y la escritura creativa.

Recibido: 10 de julio de 2018

Aprobado: 14 de septiembre de 2018 